\title{
THE APPLICATION OF MASSING HANDLING THEORY FOR EVALUATION OF THE APPLICATION OF WHARVES AND LOADING FACILITIES IN THE MARITIME PORT
}

\author{
Zbigniew Matuszak' ${ }^{1}$ Sylwia Bundz², Marek Jaśkiewicz³ , Józef Stokłosa ${ }^{4}$, Paweł Posuniak ${ }^{5}$ \\ 1 Faculty of Marine Engineering, Maritime University of Szczecin, 1-2 Wały Chrobrego St., 70-500 Szczecin, \\ Poland, e-mail: z.matuszak@am.szczecin.pl, \\ 2 Faculty of Economics and Transport Engineering, Maritime University of Szczecin, 11 H. Pobożnego St., 70- \\ 507 Szczecin, Poland, e-mail: s.bundz@am.szczecin.pl \\ 3 Department of Vehicles and Transport, Kielce University of Technology, Al. Tysiąclecia Państwa Polskiego 7, \\ 25-314 Kielce, Poland, e-mail: m.jaskiewicz@tu.kielce.pl, \\ ${ }^{4}$ High School of Economics and Innovation in Lublin, 4 Projektowa St., 20-209 Lublin, Poland, e-mail: jozef. \\ stoklosa@wsei.lublin.pl \\ ${ }^{5}$ Automotive Industry Institute (PIMOT), 55 Jagiellońska St., 03-301 Warsaw, Poland, e-mail: p.posuniak@pimot.eu
}

Received: 2016.05.31

Accepted: 2016.07.04

Published: 2016.09.01

\begin{abstract}
This work presents the general characteristics of the port system. It defines sets and functions describing the structure and work of the port. Moreover, it characterizes foundations of the massive handling theory. It provides basic literature information about selected processes and models of the massive handling theory. On the example of a transportation company serving the loading on ships in the port of Szczecin, it shows the loading method. The material loading onto ships was the sodium water glass. There are observation results of operation times comprising the data available to determine parameters of the massive handling theory. Operations covered in the analysis include: the arrival of the ship at the port's road, waiting for enter the port, passing through the fairway, waiting for loading, loading, determination of the cargo's weight, preparation of documents and waiting for leaving the port. It presents critical remarks about possibilities of using the data obtained to describe loading cargo on a ship with the use of elements of the massive handling theory.
\end{abstract}

Keywords: port system, massive handling theory, loading on ships.

\section{INTRODUCTION}

Massive handling theory, also called the theory of queues, is classified to the section of probability theory, which deals with the examination of handling processes that form a class of stochastic processes. By analyzing these processes, it becomes possible to determine and analyze the stochastic characteristics of information systems, where the information reaches in portions at random timing. These portions are called entries. Entries are processed, while the processing time of entries is a random variable. Such systems are operating systems, and the analysis of their characteristics is the subject of the massive handling theory. Such systems can include communication systems, queue at the post office, transportation crossing, etc. A common feature of any system of the massive handling is that they have three common elements $[2,5,6,8,10]$ : source of entries, queue, supporting devices. The entry is understood as all objects, which wait for service and support by handling devices and which are operated by the created handling system. By generalizing the entry is a carrier from a certain objects, which has a demand for service. The source of a 
support system in associated with the term of an input stream. The source may be treated as a set of entries for handling. Entries, which are in the source, are not formed yet and only after leaving they pass to handle are they are immediately supported or form a queue. Infinite source is visible in the situation when the lack of entry from the sources does not affect the regularities, which characterize the input stream. On the other hand, when the source has a limited number of entries, the entry, which is located in the queue after source's leaving, cannot go back to the system's entrance until it will be handled. The stream of entries is interrupted when all entries are handled, wait in a queue or left the source. It is assumed that in the finite sources, entries, which have already been served, back to the source and wait for the next handling. In such situation, the system is called a closed system.

In fact, there are systems with several sources. Some of their entries can be completed, and the other infinite. These entries can complete with each other during the entrance to the operating system what leads to the consideration of special regulations of queues and handling $[2,5,6,8,10]$.

The organization of work at the seaport includes, inter alia, the following elements: appropriate selection of ships for various wharves (from the point of view of reloading flexibility of ships, time and handling costs, minimization of ships' stopping times at the road and in port, maximum utilization of the reloading potential of waterfronts, cooperation between the port and land transport in the conveyance and export of goods. The actual organization of work in the port serves to obtain the nest economic calculation, primarily understood as the greatest profit for companies, which lease individual wharves and sets of wharves [1, 7, 11]. The study [4] analyzes three models, which successfully include the best use of the port's cargo handling capacity, minimization of contractual penalties paid to operators of vessels handled at the port and the connection of port's losses due to exceeding the time for ships' handling over the so-called normative time and an incomplete use of the wharves' reloading potential. Transformations have taken place in state enterprises and covered ports. They caused that the process of port's functioning should be considered slightly differently - mainly in terms of a broadly understood profit for companies existing in the area of the port $[3,12]$.

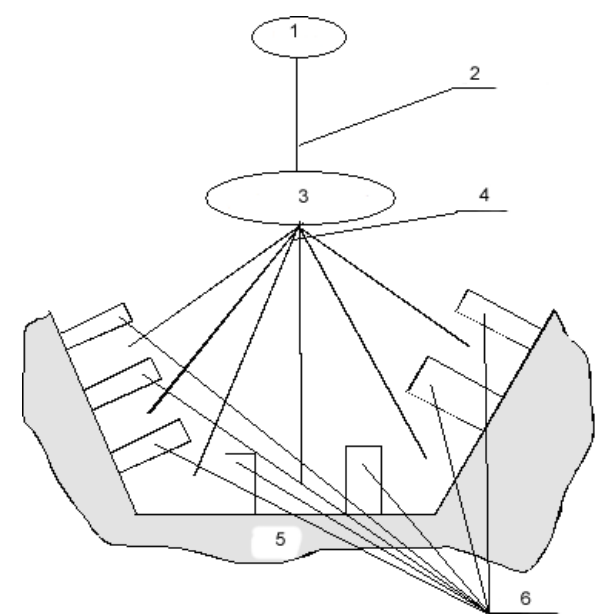

Fig. 1. The general scheme of the port: 1- roadstead; 2 - entrance to the port; 3 - roadstead-port fairway, 4 waterways and port channels; 5 - land, 6 - port wharves

\section{DESCRIPTION OF SELECTED DEPENDENCES IN THE PORT SYSTEM}

Figure 1 presents the general scheme of the port with an indication of its elements. In the port system, the following sets and functions are determined:

- a set of types of goods on ships: $P=\{1, \ldots$, $p, \ldots, P\}$

- a set of packaging types, in which goods are transported on ships: $P_{o}=\left\{1, \ldots, p_{o}, \ldots, P_{o}\right\}$;

- a set of number of ships waiting at the roadstead: $I=\{1, \ldots, i, \ldots, I\}$;

- a set of normative times of handling for ships waiting at the roadstead: $T_{n}=\left\{t_{n}^{l} \ldots, t_{n}^{i}, \ldots, t_{n}^{I}\right\}$;

- a set of individual contractual penalties for prolonged operating time of ships in the port to owners of vessels: $K=\left\{k_{l}, \ldots, k_{i}, \ldots, k_{t}\right\}$;

- a set of waiting times for service: $T_{o}=\left\{t_{o}{ }^{1} \ldots\right.$, $\left.t_{o}^{i}, \ldots, t_{o}^{I}\right\}$

- a set of wharf's length occupied by individual ships coming from the roadstead (length of the vessel with so-called a margin of safety): $D=$ $\left\{d^{l}, \ldots, d^{i}, \ldots, d^{t}\right\}$

- a set of handling capacity of ships waiting at the roadstead: $Z=\left\{z_{l}, \ldots, z_{i}, \ldots, z_{t}\right\}$;

- a set of durations for maneuvers of ships waiting at the roadstead when entering the port: $T_{m}=\left\{t_{m}{ }^{l} \ldots, t_{m}{ }^{i}, \ldots, t_{m}{ }^{I}\right\}$;

- function $F_{I}: I \times P \times P_{o} \rightarrow\left\{R^{+} \cup\{0\}\right\}$, where $K_{l}\left(i, p, p_{o}\right)=l$ when on the ship $i(i \in I)$ there is a cargo $p(p \in P)$ in a package $p_{o}\left(p_{o} \in P_{o}\right)$;

- function $F_{2}: I \times P \times P_{o} \rightarrow\left\{R^{+} \cup\{0\}\right\}$, where $\left\{R^{+} \cup\{0\}\right\}$ means a set of positive real number plus zero $F_{2}\left(i, p, p_{o}\right)>0 \Leftrightarrow F_{2}\left(i, p, p_{o}\right)=1$. 
The value of $F_{2}\left(i, p, p_{\delta}\right)$ function determines how much goods of the $p(p \in P)$ type is on board $i(i \in I)$ in package $p_{o}\left(p_{o} \in P_{o}\right)$.

It is assumed that all wharves are so large that at least one vessel $i(i \in I)$ from all ships waiting at the road can be operated by each of them. In order to analyze a model of the port, we should have certain characteristics of port's elements, i.e. roads, entrance to the port, port channels and port-road fairway, as well as handling wharves. Port channels and roadstead-port fairway are waterways, through which the movement of ships is realized. Waterways are described using the following sets and functions:

- a set of port's waterways $L=\{1, \ldots, l, \ldots, L\}$;

- function $F_{3}: L \rightarrow R^{+}$, where $F_{3}(l)$ is a length of the waterway with a number $l, R^{+}$is a set of positive real numbers;

- function $F_{4}: L \rightarrow R^{+}$, where $F_{4}(l)$ is a depth of the waterway with a number $l$;

- function $F_{5}: L \rightarrow R^{+}$, where $F_{5}(l)$ is a width of the waterway with a number $l$.

Each wharf has a handling potential $\mathrm{P}_{\mathrm{t}}$ depending on the technical equipment $(W t)$, technical condition of handling equipment $(S t)$, meteorological conditions (me), organization of handling activities $(\mathrm{Or})$, human factor $(\mathrm{Cl})$ and wharf capacity $(P n): P_{t}^{j}=F(W t, S t, m e, O r, C l, P n)$. Under certain conditions, the value of wharf's handling potential is known. The potential $P_{t}^{j}$ is expressed in arbitrary units what allows to compare the degree of certain wharf's utilization.

Sets and functions: a set of wharves in the port $\mathrm{J}=\{1, \ldots, j, \ldots, J\}$ is:

- a set of values for the wharves' handling potential $P_{p}=\left\{P_{l}, \ldots, p_{t} \ldots, P_{T}\right\}$, where: $P_{t}=$ $\left\{P_{t}^{1} \ldots, P_{t}^{p}, \ldots, P_{t}^{J}\right\}, t$ - the number of considered period of time, $j$ - number of wharf;

- a set of unit costs for unused wharves' handling potential $K_{n}=\left\{k^{l} \ldots, k^{j}, \ldots, k^{J}\right\}$;

- function $F_{6}: J \times P \times P_{o} \rightarrow\{0,1\}$, where: $F_{6}\left(j, p, p_{o}\right)=1 \Leftrightarrow$ when the type of goods $p(p \in P)$ in a package $p_{o}\left(p_{o} \in P_{o}\right)$ can be reloaded near the wharf $j(j \in J), P$ - a set of goods located on ships, $P_{o}$ - a set of packaging types, in which goods are transported on ships;

- function $F_{7}: Z \times J \times P \times P_{o} \rightarrow\left\{R^{+} \cup\{0\}\right\}$, where: $F_{7}\left(z_{i, j} p, p_{o}\right)>0 \Leftrightarrow\left[F_{6}\left(j, p, p_{o}\right)=1 \wedge F_{I}\left(i, p, p_{o}\right)=1, \mathrm{a}\right.$ value of the function determines the maximum wharf's handling capacity $j(j \in J)$ for a ship $i(i \in I)$ goods $p(p \in P)$ in a package $p_{o}\left(p_{o} \in P\right), Z$ - a set of ships' handling capacities $\left\{R^{+} \cup\{0\}\right\}$ - a set of positive real numbers plus zero.
To determine dependences in the port, it can be assumed that it is a graph $G$ comprising the following nodes:

- roadstead $(R)$,

- entrance to the port (We),

- all transshipment wharves (n),

- branches are port waterways, i.e. $G=<W$, $L, P_{1}>$, where: $\mathrm{W}=\left\{\mathrm{R}, \mathrm{We}, \mathrm{n}_{1}, \ldots, \mathrm{n}_{\mathrm{j}}, \ldots\right.$, $\left.\mathrm{n}_{\mathrm{J}}\right\}$ - a set of nodes for the graph $G, L=\{1$, ..., $l, \ldots, L\}$ - a set of nodes for the graph $G$, $P_{I}: W \times L \times W \rightarrow\{0,1\}$ - predicate that specifies the connection between nodes of the graph, e.g. $F_{4}: L \rightarrow R^{+}$, when the handling wharf with the number 1 connects to the handling wharf with the number 2 (waterways with the number 2).

The following functions are described on branches: $F_{3}: L \rightarrow R^{+}$it assigns the length for each waterway; $F_{4}: L \rightarrow R^{+}$it assigns the depth for each waterway; $F_{5}: L \rightarrow R^{+}$it assigns the width for each waterway. The set of functions described on branches for the graph $G$ is as follows: $\mathrm{F}=\left\{\mathrm{F}_{3}\right.$, $\mathrm{F}_{4}, \mathrm{~F}_{5}$ \}. In contrast, the following functions are described on the graph's nodes: $\Psi_{1}^{t}: W \rightarrow R^{+}$, $t=\overline{1}, \bar{T}$ - they assign the value of handling potential in a given period of time for each node of the graph $t ; \Psi_{2}: W \rightarrow R^{+}-$a function assigning a unit cost of the unused wharf's handling potential for each node. Therefore, the set of functions on the graph's nodes is equal to $\Psi=\left\{\Psi_{1}{ }^{1} \ldots, \Psi_{1}{ }^{\mathrm{t}}, \ldots, \Psi_{1}{ }^{\mathrm{T}}\right.$, $\left.\Psi^{2}\right\}$. In this way, the port can be described as a network $S=<G, F, \Psi>$, where $G$ - port's graph: $G=<W, L, P_{1}>, F-$ a set of function described in the graph's branches, $\Psi$ a set of functions for described graph's nodes. The following part of the work presents a model for the analysis taking into account the under-utilization of the port's cargo handling potential what is recently visible in the majority of small ports. The studies [4] characterized a model describing the minimization of port's losses incurred due to both prolongation of the total service time of ships in port over the normative time and the underutilization of the wharves' handling potential, which was illustrated by the results of handling observations on selected wharves in the port complex of Szczecin-Świnoujście.

\section{MODEL OF THE PORT SYSTEM}

The handling potential of the wharf $j(j \in J)$ is in the general case a duration of many variables, but in the considered period of time, $P_{t}^{j}$ potential 
jest is a constant value expressed in contractual units that enable a comparison of wharves with each other. One ship directed to the transshipment or unloading does not use the entire potential of the wharf, which brings losses due to the underutilization of the wharf. In order to avoid these losses, possibilities of handling multiple ships in one wharf should be used. Selection of ships should guarantee the minimization of losses incurred due to unused handling potential of wharves in considered T periods of time for all port's wharves. Function $F_{8}$ was introduced:

$$
F_{8}: I \rightarrow J \in \mathrm{R}^{+}
$$

where: $I-$ a set of ships waiting at the road, $J$-a set of port's handling wharves, $R^{+}$- a set of positive real numbers. $F_{8}(i, j)$ determines how many contractual units of the wharf's potential $j(j \in J)$ will be taken by the ship $i(i \in I)$ at the time of mooring after its positioning to the wharf $j$ to the reloading. Free potential of the wharf $j(j \in J)$ in the time interval $t$ is expressed by the following formula:

$$
W_{t}^{j}\left(x_{i j}, t_{r}(i, j)=P_{t}^{j}-\sum_{i \in I} F_{8}(i, j) \cdot y\left(x_{i j} f(t)\right)\right.
$$

where: $x_{i j}$-decision variable,

$x_{i j}= \begin{cases}1, & \text { when the ship is assigned to the wharf } j, \\ 0, & \text { in other case, }\end{cases}$

$t_{r}(i, j)$ - decision variable, the number of time period, in which the ship was moored to the wharf $j$,

$P_{t}^{j}$ - handling potential of the $j$ wharf in a time period with the number $t$,

$F_{8}(i, j) \cdot y\left(x_{i j}, f(t)\right)$ - total occupancy of the wharf's potential $j(j \in J)$ by the mooring of ships during one time interval,

$y\left(x_{i j}, f(t)\right)$ - function of the form:

$f(t)$ - function:

$$
y_{1}\left(x_{i j}, f(t)\right)=\left\{\begin{array}{l}
1, \text { when } x_{i j}=1 \wedge f(t)>0 \\
0, \text { when } x_{i j}=0 \vee f(t) \leq 0
\end{array}\right.
$$

$$
f(t)=t(i, j)-\left[t-t_{r}(i, j)\right]
$$

$t(i, j)$ - duration of ship's stay at the wharf $j$,

$t$ - number of current period.

Duration of ship's stay $i(i \in I)$ at the wharf $j(j \in J)$ is expressed by the formula:

$$
t(i, j)=t_{p}\left(z_{i}, j, p, p_{0}\right)+t_{z}(i, j)
$$

where: $t_{p}\left(z_{i} j, p, p_{0}\right)$ - duration of the ship's reloading $i(i \in I)$ in the wharf $j(j \in J)$ :

$$
t_{p}\left(z_{i}, j, p, p_{0}\right)=\frac{F_{2}\left(i, p, p_{o}\right)}{F_{7}\left(z_{i}, j, p, p_{o}\right)}
$$

$t_{z}(i, j)$ - zero time; the total waiting time to start handling $i$ - of this ship after the mooring to $j$-this wharf and leaving the berth after the completion of reloading.

Losses occurred due to non-used potential of the wharf $j(j \in J)$ in the time interval: $t(t=1, \bar{T})$ are expressed by the formula:

$$
K_{t}^{j}\left(x_{i, j}, t_{r},(i, j)\right)=W_{t}^{j}\left(x_{i, j}, t_{r},(i, j)\right) k^{j}, \quad j=1, \bar{J}
$$

where: $\mathrm{k}^{\mathrm{j}}$ - unit cost of unused potential of the $\mathrm{j}$ wharf.

Losses occurred due to the non-used potential of the wharf $j(j \in J)$ in $T$ time intervals:

$$
K^{j}\left(x_{i, j}, t_{r},(i, j)\right)=\sum_{j=\overline{1}, \bar{J}}^{T} K^{j}\left(x_{i, j}, t_{r},(i, j)\right)=\sum_{t=1}^{T} W_{t}^{j}\left(x_{i, j}, t_{r},(i, j)\right) k^{j}
$$

Analogously, losses for the entire port in considered $T$ time intervals, i.e. for all wharfs $j(j \in J)$, are expressed by the formula:

$$
\begin{aligned}
K\left(X, T_{r}\right) & =\sum_{j \in J} K^{j}\left(x_{i, j}, t_{r}(i, j)\right)=\sum_{j \in J} \sum_{t=1}^{T} K^{j}\left(x_{i, j}, t_{r}(i, j)\right)=\sum_{j \in J} \sum_{t=1}^{T} W^{j}\left(x_{i, j}, t_{r}(i, j)\right) \cdot k^{j}= \\
& =\sum_{j \in J} \sum_{t=1}^{T}\left[P_{t}^{j}-\sum_{i \in I} F_{8}(i, j) \cdot y\left(x_{i, j}, f(t)\right)\right] \cdot k^{j}
\end{aligned}
$$


where: $X$ - matrix $\left[x_{i, j}\right]_{I \times j}$,

$$
T_{r} \text { - matrix }\left[t_{r}(i, j)\right]_{I \times J}
$$

Decision variables for the problem are $x_{i, j}$, $t_{r(i, j)}$, which mean:

$x_{i j}=\left\{\begin{array}{l}1, \text { when the ship is assigned to the wharf } j, \\ 0, \text { in other case, }\end{array}\right.$

where: $t_{r}(i, j)$ - it determines in which time interval the $i$ ship was moored to the $j$ wharf.

A pair $\left(x_{,} t_{r}(i, j)\right)$ determines the time interval $i(i \in I)$, in which the ship will be directed to the wharf $j(j \in J)$, i.e. it specifies the operating schedule of the $i$ ship in the port.

The function of the problem criterion is a function determined as:

$$
K\left(X, T_{r}\right)=\sum_{j \in J} \sum_{t=1}^{T}\left[P_{t}^{j}-\sum_{i \in I} F_{8}(i, j) \cdot y\left(x_{i, j}, f(t)\right)\right] \cdot k^{j}(10)
$$

Matrix $X$ and $T_{r}$ create a plan of handling for the port during considered time intervals $T$. This plan determines the section $t_{r(i, j, j)}$, in which the ship $i(i \in I)$ should be moored to the wharf $j(j \in J)$.

As a final effect, the task tries to determine the optimal plan for handling ships in the port $X^{*}, T_{r}^{*}$, i.e. such a plan, which will minimize the criterion function, i.e. the underutilization of the port's handling potential. Therefore, it should be determined:

$$
\left(X^{*}, T_{r}^{*}\right) \in \Omega: K\left(X^{*}, T_{r}^{*}\right)=\min _{\left(X, T_{r}\right) \in \Omega} K\left(X, T_{r}\right)
$$

where: $\Omega-$ a set of acceptable solutions, which is a set of all matrices $X=\left[x_{i, j}\right]_{I \times, j}$,

$T_{r}=\left[t_{r}(i, j)\right]_{I \times \rho}$, which elements meet the restrictions:

1) $\underset{i \in I}{\wedge} x_{j \in J} x_{i, j} \in\{0,1\}$

2) $\wedge \wedge 1 \leq \mathrm{t}_{\mathrm{r}}(i, j) \leq T$ $i \in I, j \in J$

3) $\underset{j \in J}{\wedge} t=\overline{1}, \bar{T} \sum_{i \in \mathrm{I}} F_{8}(i, j) y\left(x_{i, j}, f(t)\right) \leq P_{t}^{j}$

the condition ensuring the wharf's cargo handling capacity will not be exceeded,

4) $\hat{i \in I}_{j \in J} x_{i, j}=1 \Leftrightarrow F_{7}\left(z_{i}, j, p, p_{o}\right)>0$

ship $i(i \in I)$ can be reloaded at the wharf $j(j \in J)$, which is a wharf acceptable due to the type of cargo $p(p \in P)$ transported in the package $p_{o}\left(p_{o} \in P_{0}\right)$ on the ship with the handling capacity $z_{i}\left(z_{i} \in Z\right)$.

\section{CHARACTERISTICS OF SELECTED PROCESSES AND MODELS OF THE MASSIVE HANDLING THEORY}

The model, which will be adopted for the analysis of the massive handling system, depends on elements creating this system. Kendall symbols $[3,4]$ are used for a brief designation of simple handling systems: $A / B / n / m(A-$ the type of input stream, $A=M$ Markov stream; $B$ - distribution type of service time, $B=M$ exponential distribution of service time; $n$ - the number of identical devices use; $\mathrm{m}$ - the number of seats to wait in line). In most cases, massive handling systems contain several work stations, and the organization of the queue is usually very complex. Systems with one operating position are most popular in the theoretical analysis, just like systems with multiple positions based on one queue and service in accordance with the registration order. In the $M / M / 1$ system with an unlimited queue, there is a massive handling system, wherein:

- stream of entries is a random process consistent with the Poisson distribution (or exponential) with $\lambda$ intensity,

- there is one operating apparatus with a duration of service consistent with the exponential distribution with $\mu$ intensity,

- queue regulations states that entries waiting for the service in an unlimited queue and they are serviced in accordance with the place occupied in the queue.

In the $\mathrm{M} / \mathrm{M} / 1$ system with a limited queue, there is a massive handling system, wherein:

- stream of entries is a random process consistent with the Poisson distribution (or exponential) with $\lambda$ intensity,

- there is one operating apparatus with a duration of service consistent with the exponential distribution with $\mu$ intensity,

- queue regulations states that the entry, facing with $\mathrm{m}$ entries during the arrival, resigns from waiting for service.

Resignation occurs when there are $s-1$ entries in the queue and one entry is currently realized. In the $M / M / m$ system with an unlimited queue, there is a massive handling system, wherein:

- there are m operating apparatuses characterized in that the durations of use realized by individual apparatuses are random variables compatible with the exponential distribution $\mathrm{m}$ with the same $\mu$ intensity, 
- stream of entries to the system is a simple stream with $\lambda$ intensity,

- regulations of the queue states that if all apparatuses are occupied, entries are placed in one queue and they are handled in order of application by the free apparatus of service.

In the $\mathrm{M} / \mathrm{M} / \mathrm{m}$ system with a complete resignation from the waiting for the service's beginning, when all apparatuses are occupied, the entry does not wait for the service, but it leaves the system resulting in the loss of entry when all available operating apparatuses are occupied. When considering the $\mathrm{M} / \mathrm{M} / \mathrm{m}$ system with a complete resignation from the waiting for the service' beginning, it is assumed that:

- stream of entries in consistent with the Poisson distribution (exponential) with $\lambda$ intensity,

- duration of the use by individual operating apparatuses are compatible with the exponential distribution of equal $\mu$ intensity, if there is at least one free apparatus at the time of notification, its service is immediately realized.

\section{RANGE OF COMPANY'S BUSINESS ACTIVITY}

The transport company serving shipments on ships in the port of Szczecin, which helped to describe the loading with the use of elements from the massive handling theory, has four international reloading terminals: Warszawa-Błonie, Dąbrowa Górnicza, Poznań-Sady and WrocławBielany. Furthermore, the company has seven regional reloading terminals: Warszawa-Błonie, Dąbrowa Górnicza, Poznań-Sady, WrocławBielany, Łódź, Bydgoszcz and Cracow. Within the country it offers the "door to door" delivery in 24 hours, and across Europe - delivery time is between 24 to 72 hours. Branch of the company in Szczecin operates primarily in the port of Szczecin. The seaport is an economic object situated on the contact of land and sea, prepared in terms of technical and organizational technology to handle international and domestic commodity turnovers carried out by the sea and means of sea and land transport involved in their transportation.

The seaport consists of two main parts: aquatorium and territory $[5,7]$. The aquatorium is a water part of the port, which consists of: road with anchorage, where ships await to enter the port; outer harbor, i.e. an area of direct entrance to the port; port channels and docks. The territory used primarily for cargos and vessels is composed of: breakwaters; port wharves and jetties; facilities - i.e. stores, storage yards and building for various purposes. The basic elements of the port are port terminals. The terminal is a concept that combines the wharf and its facilities. Port cargo handling terminal is generally a legally, organizationally and economically separated unit. Individual terminals specialize in handling (reloading) specific cargos from the means of sea transport to the means of land transport and vice versa, transshipments in ship-yard-ship relation, as well as storage, warehousing and manipulations of cargos in the port $[5,7]$.

Elements of the massive handling system will be presented on the example of sodium water glass - a cargo operated by the company in export. The company for the handling of sodium water glass and stainless steel scrap makes use of the Bulk Cargo-Port Szczecin terminals in the port of Szczecin. Bulk Cargo-Port Szczecin is a universal transshipment and storage company, serving all groups of cargos passing through the port in the mount of the Oder. Sodium water glass (Fig. 2) is loaded from a wharf in an indirect relation, i.e. from the years to the ship via 1 or 2 wharf cranes with a clamshell grab. An attempt to use selected elements of the massive handling for describing the operation of transshipment The transshipment of sodium water glass (Fig. 2, Fig. 3, Fig 4) performed by the company, is realized directly from the wharf (storage yard). Working changes in the port starts successively at 6 a.m., 2 p.m. ad 10 p.m. The port operates cargos 24 hours a day on working days. Table 1 presents durations of all operations concerning

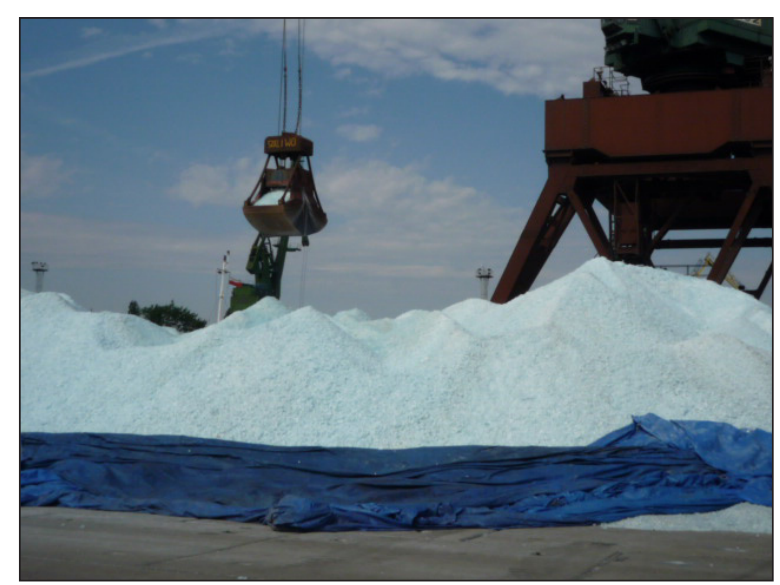

Fig. 2. The storage of the sodium water glass 


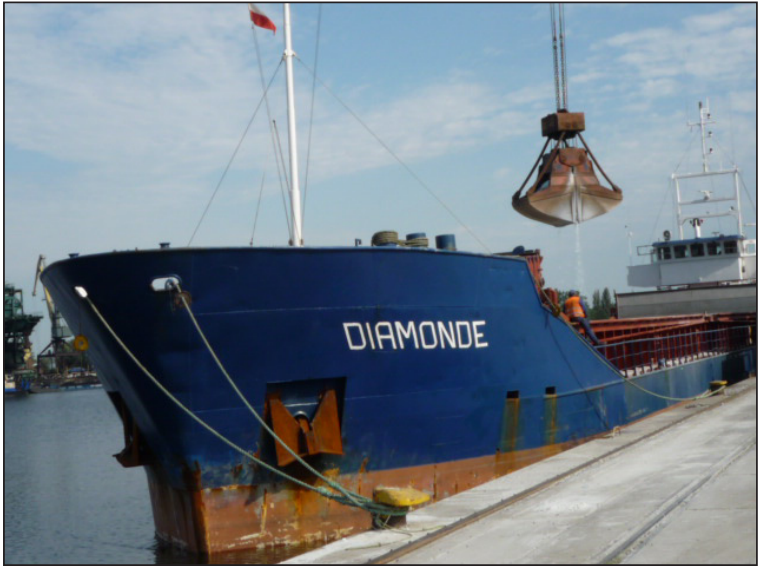

Fig. 3. The handling of the sodium water glass

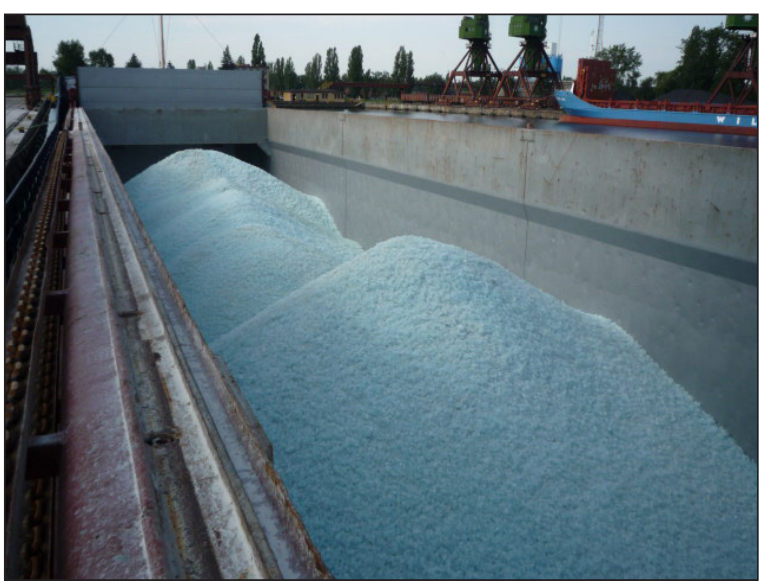

Fig. 4. Sodium silicate in the ship's hold

Table 1. Durations of individual operations for the transshipment of 1850 tons of sodium water glass

\begin{tabular}{|l|c|c|c|c|c|}
\hline \multicolumn{1}{|c|}{ Date } & \multicolumn{2}{c|}{ 26.01.2013-28.01.2013 } \\
\hline \multicolumn{1}{|c|}{ Activity } & Working hours & \multicolumn{2}{c|}{ Hours of downtime } \\
\cline { 2 - 5 } & from & to & \multicolumn{2}{c|}{ from } & $09: 00$ \\
\hline Arrival at the roadstead & & & & 26.01 .2013 \\
\hline Waiting to enter the port & & & $09: 00$ & $00: 00$ \\
\hline Waiting to enter the port & & & $00: 00$ & $17: 15$ \\
\hline Passing through the fairway & & & $17: 15$ & $22: 45$ \\
\hline Waiting for loading & & & $22: 45$ & $00: 00$ \\
\hline Waiting for loading & & & $00: 00$ & 27.01 .2013 \\
\hline Loading & $06: 30$ & $13: 10$ & & 27.01 .2013 \\
\hline Determination of the cargo's weight & & & $13: 10$ & $13: 40$ & 2813 \\
\hline Preparation of documents & & & $13: 40$ & $15: 10$ & 28.01 .2013 \\
\hline Waiting to leave the port & & & $15: 10$ & $15: 30$ & 28.01 .2013 \\
\hline
\end{tabular}

the loading of sodium water glass on the ship in the amount of 1850 tons, from the arrival of this vessel at the road to the exit from the port. Sodium water glass was loaded from the storage yard to the ship (Fig. 2, Fig. 3) with the use of one loading device.

Table 2 shows the durations of all operations concerning the loading of sodium water glass on the ship in the amount of 1745 tons, from the arrival of this vessel at the road to the exit from the port. Sodium water glass was loaded from the storage yard to the ship with the use of one loading device.

Data contained in Tables 1 and 2 and additional observations, which were not included in this study due to the lack of space, allowed to es-

Table 2. Durations of individual operations for the transshipment of 1745 tons of sodium water glass

\begin{tabular}{|l|c|c|c|c|c|}
\hline \multicolumn{1}{|c|}{ Date } & \multicolumn{5}{c|}{$13.03 .2013-14.03 .2013$} \\
\multirow{2}{*}{ Activity } & \multicolumn{2}{c|}{ Working hours } & \multicolumn{2}{c|}{ Hours of downtime } & \multirow{2}{*}{ Date } \\
\cline { 2 - 6 } & from & to & from & to & \\
\hline Arrival at the roadstead & & & & $21: 00$ & 13.03 .2013 \\
\hline Passing through the fairway & & & $21: 00$ & $00: 00$ & 13.03 .2013 \\
\hline Passing through the fairway & & & $00: 00$ & $01: 05$ & 14.03 .2013 \\
\hline Waiting for loading & & & $01: 05$ & $06: 30$ & 14.03 .2013 \\
\hline loading & $06: 30$ & $12: 30$ & & & 14.03 .2013 \\
\hline Determination of the cargo's weight & & & $12: 30$ & $12: 50$ & 14.03 .2013 \\
\hline Preparation of documents & & & $12: 50$ & $14: 10$ & 14.03 .2013 \\
\hline Waiting to leave the port & & & $14: 10$ & $14: 30$ & 14.03 .2013 \\
\hline
\end{tabular}


timate values concerning the service of sodium water glass:

- intensity of $\lambda$ entries: $\lambda=1.83 / 6, \lambda=0.05$;

- intensity of $\mu$ service: $\mu=1 / 2, \mu=0.5$.

\section{CONCLUSIONS}

The presented analysis presents in a very simplified way the issue of massive handling. However, it indicates whether the current operating systems are sufficient and whether it is worth to develop them or not in order to increase the throughput of these systems. Thanks to the above information it is possible to prepare a scheme allowing the minimization of losses resulting from waiting for service and ensuring the continuity in handling.

Summary statement for durations of loading operations showed time differences between individual operations. In all cases concerning the sodium water glass, times, directly related to the service of cargo (which can include: loading, preparation of documents, determination of cargo's weight) were very similar to each other. The queue is minimized almost to zero, because ships approach the wharf without a long waiting on the road. Due to loadings at the port, carried out only on working days, in the case of ships reaching the port on Friday or later, it must wait for the loading to the next week. Lots of cargos are very close to each other (approx. 2000 tones), and the loading time is similar. The obtained data allowed determining two basic parameters characterizing the massive handling: intensity of entries and intensity of service. The intensity of entries amounted to 0.305 , which means that during the day about 0.3 of a ship is handled, i.e. about one ship per every three days. The intensity of service amounted to 0.5 of a ship per day, i.e. ships are handled with an intensity of one in two days. Stoppages in loading work, pauses and waiting to enter the port and then to start loading proved to be the most irregular. Waiting time may result from the specificity of the port - i.e. cargos are handled only from Monday to Friday, 24 hours a day.

\section{REFERENCES}

1. Bichou K., Gray R. A logistics and supply chain management approach to port performance 31 measurement. Maritime Policy \& Management, 31(1), 2004, 47-67.

2. Byśko J., Cygan Z. Sterowanie eksploatacją granicznego rejonu przeładunkowego PKP. Z. Cygan [red.] Sterowanie i zarządzanie eksploatacją systemów technicznych, Vol. V, n. I, PWN, Warszawa 1985.

3. Carbone V., Martino M.D. (): The changing role of ports in supply-chain management: an 3 empirical analysis. Maritime Policy \& Management, 30(4), 2003, 305-320.

4. Cygan Z., Dziadykiewicz L. Optymalizacja sterowania ruchem statków w porcie. S. Zięba [red.] Sterowanie i zarządzanie eksploatacją systemów technicznych, Vol. II, PWN, Warszawa 1985.

5. Gniedenko B.W., Kowalenko I.N. Wstęp do teorii obsługi masowej. PWN, Warszawa 1971.

6. Kalashnikov V.V.: Mathematical Methods in Queuing Theory. Kluver Academic Publishers Group. Dordrecht, The Netherlands, 1994.

7. Martagan T.G., Eksioglu B., Eksioglu S.D., Greenwood A.G.: A simulation model of port 10 operations during crisis conditions. Winter Simulation Conference. Winter Simulation Conference, 11, 2009, 2832-2843.

8. Matuszak K., Matuszak Z. Opis pewnego systemu portowego. Materiały Konferencji Naukowo-Technicznej EXPLO-SHIP '99 „Problemy eksploatacji statków morskich i śródlądowych oraz urządzeń portowych", Szczecin-Międzyzdroje-Kopenhaga, 1999, 83-90.

9. Matuszak Z., Wrycz A. Analiza systemu portowego małego portu morskiego środkowego wybrzeża Polski. Collection of research papers of the Baltic Association of Mechanical Engineering Experts No. 3, Mechanical Engineering of the Baltic Region, Kaliningrad State Technical University, Kaliningrad, 2003, 62-66.

10. Obretenow A., Dimitrow B. Teoria masowej obsługi. Poradnik. PWN, Warszawa 1989.

11. Stopford M.: Maritime Economics, 3rd edition. Routledge, London; New York 2008.

12. Tsinker G.P.: Port engineering: planning, construction, maintenance, and security. John Wiley \& 5 Sons, 2004. 